\title{
To Study the Slurry Erosion Behaviour of Hard Faced Alloy SS304
}

\author{
Amandeep Singh, Roshal Lal Virdi, Khushdeep Goyal \\ Department of Mechanical Engineering, Punjabi University, India \\ *Corresponding Author: khushgoyal@yahoo.com
}

Copyright $@ 2014$ Horizon Research Publishing All rights reserved.

\begin{abstract}
Slurry erosion of impellers decreases the efficiency of impellers up to 5-10\%. The slurry erosion depends upon many parameters viz. silt size, concentration, hardness of particles, velocity of water etc. In this research work the effect of these parameters has studied on the hard facing of SS 304 with hard alloy III and titanium alloy. It is found that hard facing helps to increase the erosion resistance properties of the substrate material.
\end{abstract}

Keywords Slurry, Erosion, Hard Facing, Impact Angle, Slurry Concentration

\section{Introduction}

Slurry erosion is the removal of material from the surface by the repeated impingement of hard particles moving at considerable velocities. It is a serious problem in flow through pipes, hydraulic systems and impellers. Erosion of hydroturbine components has received important attention in recent past [1]. Hard facing is one of important method to increase the erosion resistance of these components. It helps to increase the life of the components. Welding is important process to apply hard facing alloys on a substrate material [2].

In recent past, many researches had tried to improve the erosion resistance of hydro components such as impellers. Goyal et al. [3] investigated the erosion performance of $\mathrm{WC}-$ $10 \mathrm{Co}-4 \mathrm{Cr}$ and $\mathrm{Al}_{2} \mathrm{O}_{3}$ and $13 \mathrm{TiO}_{2}$ coatings on $\mathrm{CF} 8 \mathrm{M}$ turbine steel. It was found that $\mathrm{WC}-10 \mathrm{Co}-4 \mathrm{Cr}$ coatings are more useful to increase slurry erosion than other coatings. Grewal et al. [4] investigated performance of $\mathrm{Ni}-\mathrm{Al}_{2} \mathrm{O}_{3}$ based composite coatings. The authors found that fracture toughness controls the erosion resistance of coatings. It was also found that the content of alumina have significant influence on erosion performance of the coatings. Wood et al. [5] studied the surface response of stainless 316 alloy. The authors tested the samples in slurry pot apparatus using 1\% uncrushed silica at $7 \mathrm{~m} / \mathrm{s}$ for $60 \mathrm{~min}$, both in water and $3.5 \%$ $\mathrm{NaCl}$ solution. Influence of cooling rate on the microstructure and wear performance of $\mathrm{Fe}-\mathrm{Cr}-\mathrm{C}$ hardfacings was studied by Hornung et al. [6]. Kin et al. [7] investigated the effect of manganese and boron on the erosion behavior of austenitic $\mathrm{Fe}-\mathrm{Cr}-\mathrm{C}-\mathrm{Si}-x \mathrm{Mn}-y \mathrm{~B}(x=0$, $10 \mathrm{wt} \%, y=0,0.3 \mathrm{wt} \%$ ) hardfacing alloys. Tefler et al. [20] mae a comparison between erosion-corrosion mechanisms of $\mathrm{Fe}, \mathrm{Ni}, \mathrm{Al}$, and $\mathrm{Cu}$ under different conditions of particle size and concentration. Bermudez et al. [8] investigated erosion-corrosion behavior of stainless steel AISI 304L and 316L. It was found that higher amount of mass loss was due to angular silicon carbide particles. Singh et al. [9] investigated the effect of various parameters on slurry erosion mechanism of uncoated and coated CA6NM steel. It was found that maximum erosion takes place at $90^{\circ}$ impingement angle. The SEM analysis revealed that erosion mechanism of CA6NM steel under normal impact is platelet mechanism but for coating under similar condition is due to crack formation. It is clear from the literature survey that many authors have done studies of erosion performance of different type of coatings, but less literature is available on erosion behaviour of hard facing alloys. Therefore, in this research work slurry erosion behaviour has been investigated by studying the effect of hard facing of SS 304 with hard alloy III and Titanium alloy. Hard facing is comparatively less expensive than the coatings, and it increases the erosion resistance of different types of steels.

\section{Experimentation}

\section{Test Material}

The substrate material was selected on the basis of its cost and the availability. The SS 304 material was procured from Bombay Steels, Ludhiana (Punjab). The detailed composition of material used i.e.SS 304 is shown in table 1.

\section{Hard Facing}

The hard facing of SS 304 was done with submerged arc welding technique with Hard Alloy III and Titanium alloy. The two types of hard facing coatings were obtained from these two alloys. The hard-facing of SS 304 was done at Punjabi university, Patiala. 
Table 1. Chemical composition of SS 304

\begin{tabular}{|c|c|c|c|c|c|c|c|c|c|c|c|c|}
\hline Element & $\mathrm{C}$ & $\mathrm{Si}$ & $\mathrm{Mn}$ & $\mathrm{P}$ & $\mathrm{S}$ & $\mathrm{Cr}$ & $\mathrm{Mo}$ & $\mathrm{Ni}$ & $\mathrm{Co}$ & $\mathrm{Ti}$ & $\mathrm{V}$ & $\mathrm{Fe}$ \\
\hline \% age & 0.078 & 0.346 & 1.02 & 0.031 & 0.006 & 18.78 & 0.203 & 8.18 & 0.07 & 0.003 & 0.064 & 71.12 \\
\hline
\end{tabular}

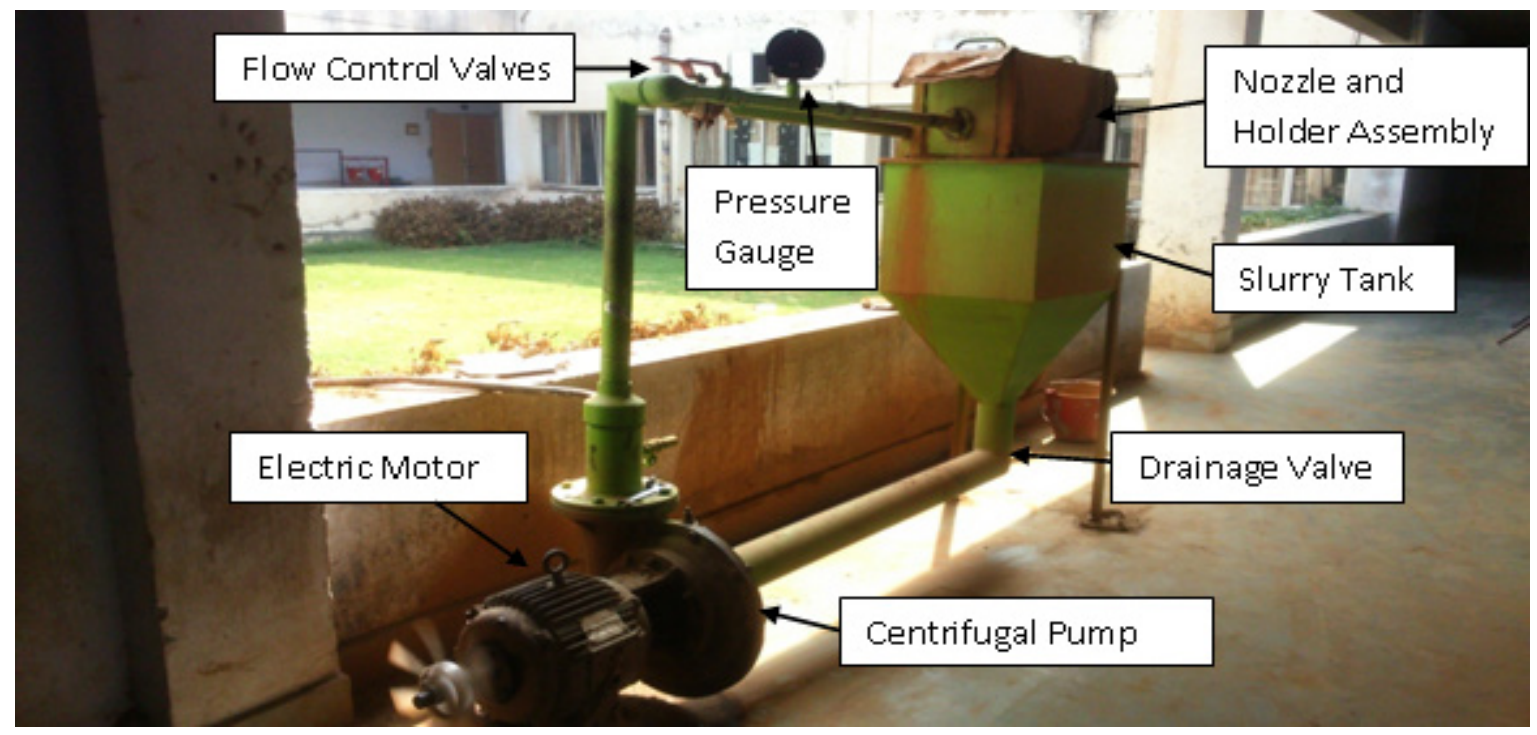

Figure 1. Jet Erosion Tester

\section{Experimentation Apparatus}

Figure 1 shows the test apparatus which has been designed and developed at Punjabi University, Patiala.

\section{Results and Discussions}

\section{Erosion Performance of SS 304, Hard Alloy III and Titanium coating}

The erosion performance of SS 304, Hard Alloy III and Titanium coatinghas been evaluated by varying velocity, impact angle and concentration level. The effect of time on weight loss while varying different parameters is also evaluated with effect of each parameter. The effect of time on weight loss is reported first. Nine experiments were performed for each parameter. Hard alloy III hard facing is named as Alloy 1 and hard facing of titanium is named as Alloy 2

Table 2. Mass loss in $\mathrm{mg} / \mathrm{cm}^{2}$ w. r. t. time at various runs for hard alloy III

\begin{tabular}{|c|c|c|c|c|c|}
\hline & $0 \mathrm{~min}$ & $30 \mathrm{~min}$ & $60 \mathrm{~min}$ & $90 \mathrm{~min}$ & $120 \mathrm{~min}$ \\
\hline Run 1 & 0 & 0.5333 & 1.0666 & 1.8666 & 2.4 \\
\hline Run 2 & 0 & 0.8 & 1.4666 & 2.6666 & 3.8666 \\
\hline Run 3 & 0 & 2 & 3.0666 & 5.6 & 7.7333 \\
\hline Run 4 & 0 & 0.6666 & 1.4666 & 3.3333 & 5.2 \\
\hline Run 5 & 0 & 0.8 & 2.1333 & 3.3333 & 4.5333 \\
\hline Run 6 & 0 & 0.5333 & 1.4666 & 3.0666 & 4.6666 \\
\hline Run 7 & 0 & 0.9333 & 2.8 & 4.8 & 6.2666 \\
\hline Run 8 & 0 & 0.8 & 2.1333 & 3.4666 & 5.7333 \\
\hline Run 9 & 0 & 1.3333 & 2.8 & 4.6666 & 6 \\
\hline
\end{tabular}

\section{Mass loss for Hard Alloy III at different runs}

The mass loss for hard alloy III at different experimental runs is shown in table 2 .

Figure 2 shows the mass loss at various time intervals for all nine experimental runs. It is clear that erosion is maximum for run 3, where velocity is $60 \mathrm{~m} / \mathrm{sec}$, concentration is maximum, the angle of impingement if $90^{\circ}$. Similar results have been reported by Singh et al. [9].

\section{Mass loss for titanium based hardfacing at different runs}

The mass loss for titanium based hard facing at all nine experimental is shown in table 3 and figure 3 shows the comparative line chart for all runs.

Table 3. mass loss in $\mathrm{mg} / \mathrm{cm}^{2}$ w. r. t. time at various runs for titanium based alloy

\begin{tabular}{|c|c|c|c|c|c|}
\hline & $0 \mathrm{~min}$ & $30 \mathrm{~min}$ & $60 \mathrm{~min}$ & $90 \mathrm{~min}$ & $120 \mathrm{~min}$ \\
\hline Run 1 & 0 & 0.4 & 0.9333 & 1.4666 & 2 \\
\hline Run 2 & 0 & 0.5333 & 1.2 & 2.1333 & 3.0666 \\
\hline Run 3 & 0 & 1.3333 & 2.8 & 5.2 & 7.4666 \\
\hline Run 4 & 0 & 0.4 & 1.0666 & 1.8666 & 3.0666 \\
\hline Run 5 & 0 & 0.5333 & 1.4666 & 3.0666 & 4.1333 \\
\hline Run 6 & 0 & 0.4 & 0.8 & 2.4 & 3.6 \\
\hline Run 7 & 0 & 0.4 & 0.9333 & 1.8666 & 3.0666 \\
\hline Run 8 & 0 & 0.6666 & 1.4666 & 2.9333 & 4.2666 \\
\hline Run 9 & 0 & 0.9333 & 2 & 4.2666 & 5.4666 \\
\hline
\end{tabular}




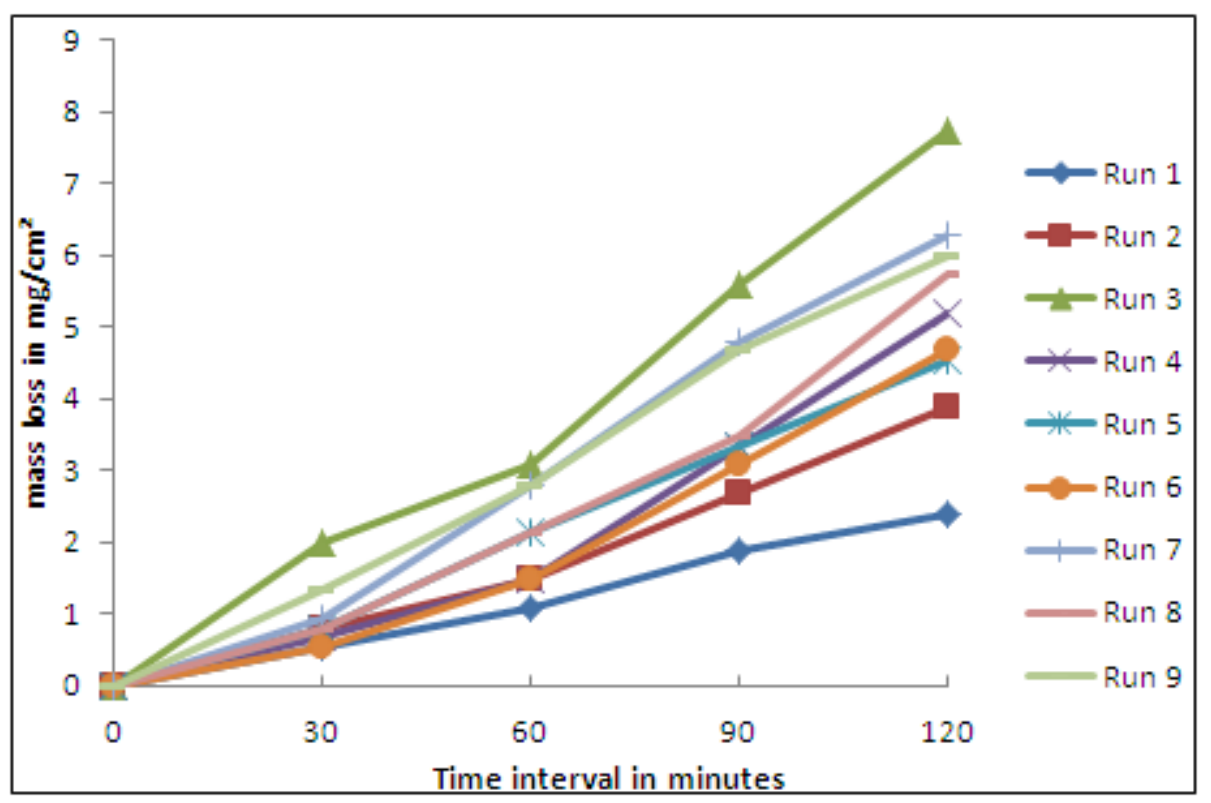

Figure 2. Mass loss for hard alloy III at different runs

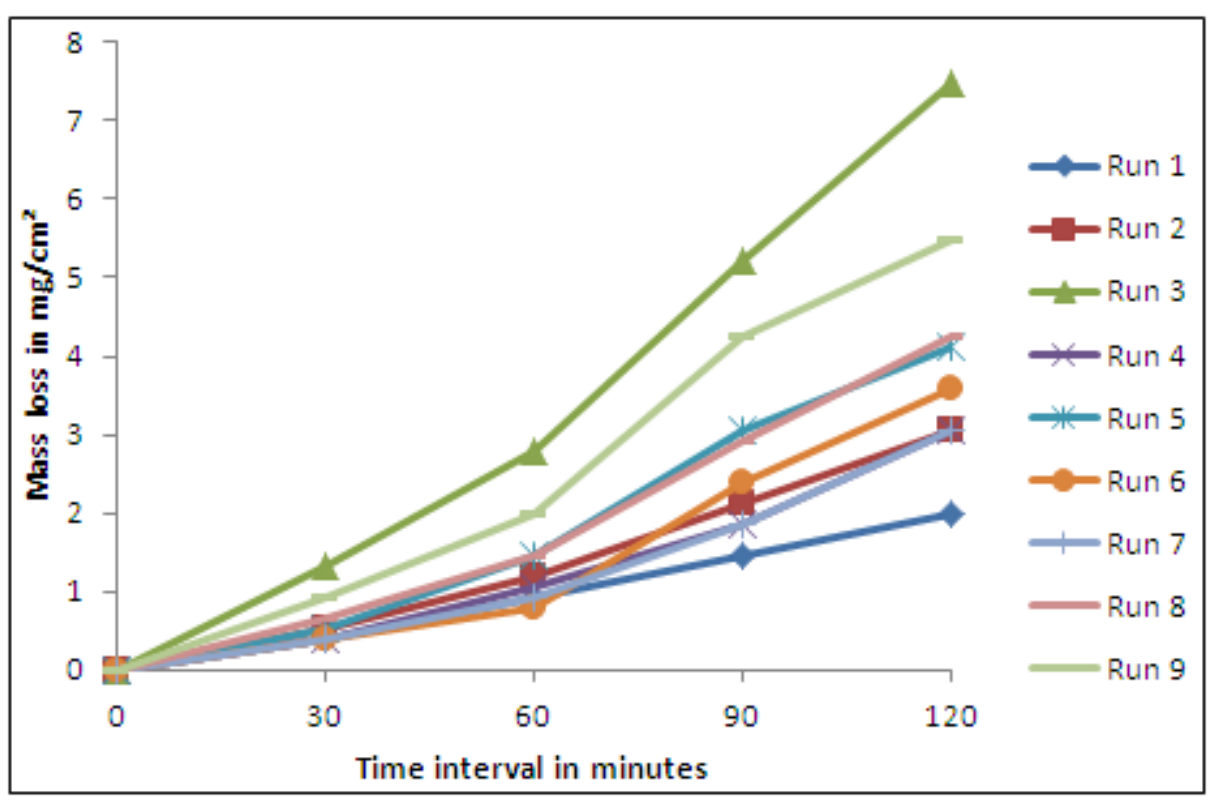

Figure 3. Mass loss for titanium based Hardfacing at different runs

It is clear that erosion is maximum for run 3 , where velocity is $60 \mathrm{~m} / \mathrm{sec}$, concentration is maximum, the angle of impingement if $90^{\circ}$. The erosion is minimum for experiment run number 7 which is at $30^{\circ}$ impingement angle. Similar results have been reported by Singh et al. [9].

\section{Mass loss for uncoated SS 304 steel at different runs}

Table 4 and figure 4 show the mass loss in $\mathrm{mg} / \mathrm{cm}^{2} \mathrm{w}$. r. t. time at various runs for SS 304 steel.

It is clear that erosion is maximum for run 3 , where velocity is $60 \mathrm{~m} / \mathrm{sec}$, concentration is maximum, the angle of impingement if $90^{\circ}$ and minimum for run 7 , where the angle is $30^{\circ}$. Similar results have been reported by Singh et al. [9].
Table 4. Mass Loss with respect to time

\begin{tabular}{|c|c|c|c|c|c|}
\hline & $0 \mathrm{~min}$ & $30 \mathrm{~min}$ & $60 \mathrm{~min}$ & $90 \mathrm{~min}$ & $120 \mathrm{~min}$ \\
\hline Run 1 & 0 & 0.5333 & 1.2 & 1.8666 & 2.6666 \\
\hline Run 2 & 0 & 1.2 & 2 & 3.2 & 5.6 \\
\hline Run 3 & 0 & 2.4 & 5.6 & 8.1333 & 10.9333 \\
\hline Run 4 & 0 & 1.3333 & 2.1333 & 4.2666 & 6 \\
\hline Run 5 & 0 & 1.2 & 2.5333 & 4.5333 & 7.7333 \\
\hline Run 6 & 0 & 1.066 & 2.4 & 3.8666 & 5.8666 \\
\hline Run 7 & 0 & 1.3333 & 2.5333 & 4.9333 & 7.3333 \\
\hline Run 8 & 0 & 1.4666 & 3.0666 & 5.2 & 6.9333 \\
\hline Run 9 & 0 & 1.8666 & 3.8666 & 6.5333 & 10.2666 \\
\hline
\end{tabular}




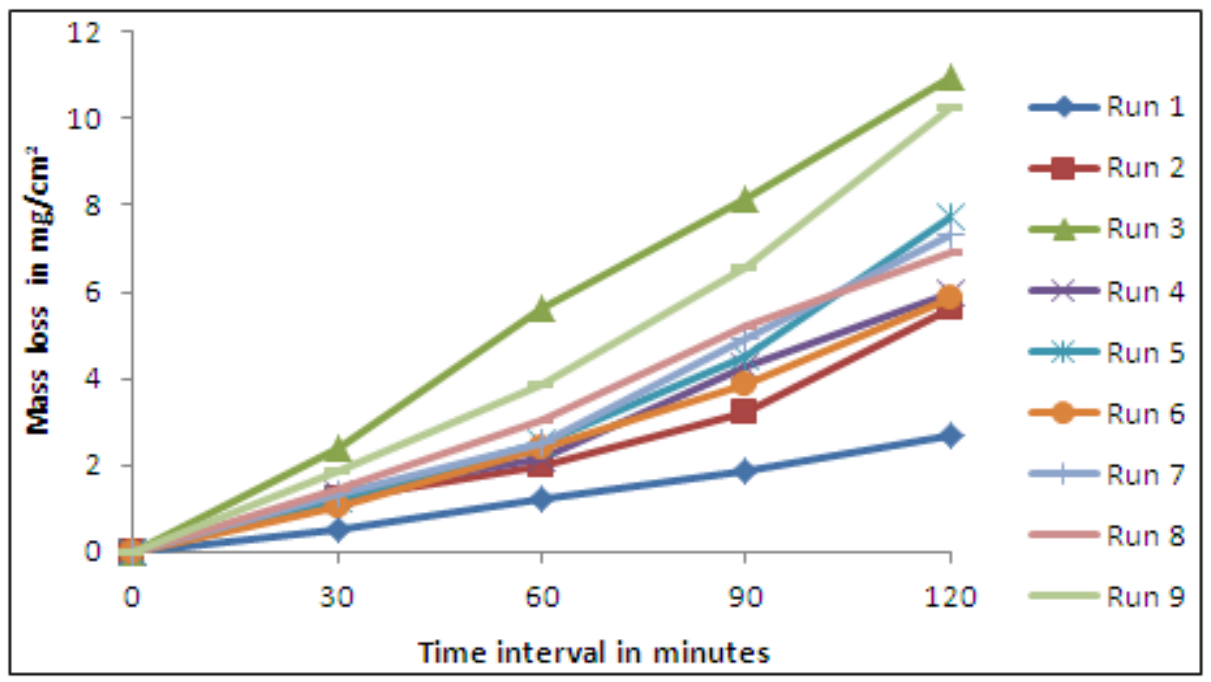

Figure 4. Mass loss for uncoated SS 304 steel at different runs

\section{Sem Analysis}

The SEM analysis of samples used for erosion purpose was examined at the Sophisticated Instrument Centre, Punjabi University, Patiala with help of scanning electron microscope (JSM 6510) to visualize change in microstructure in order to know the mechanism of erosion.

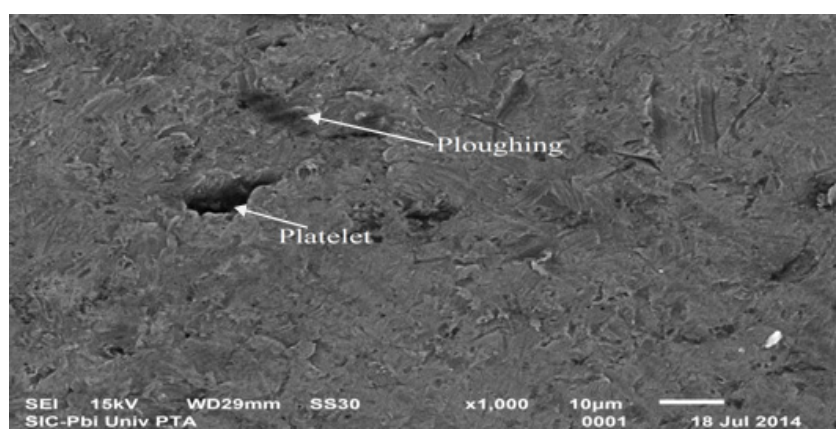

Figure 5. SEM micrograph of Hard Alloy III

The figure 5 shows the SEM micrograph of hard alloy III at conditions $150 \mu \mathrm{m}$ particle size, $10000 \mathrm{ppm}$ concentration level, $20 \mathrm{~m} / \mathrm{sec}$ velocity and $30^{\circ}$ angle of impingement. At these conditions least erosion has been studied and defects occurred are ploughing and platelet defects.

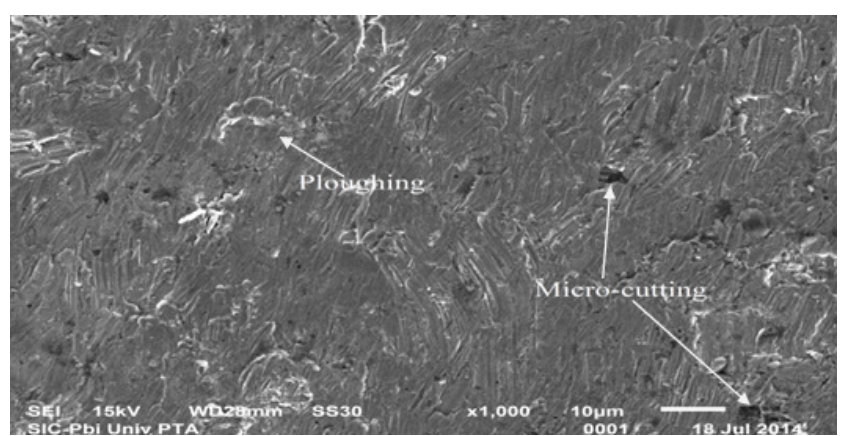

Figure 6. SEM micrograph of titanium based alloy
The figure 6 shows the SEM micrograph of Titanium at conditions $150 \mu \mathrm{m}$ particle size, $10000 \mathrm{ppm}$ concentration level, $20 \mathrm{~m} / \mathrm{sec}$ velocity and $30^{\circ}$ angle of impingement. At these conditions least erosion has been studied and defects occurred are ploughing and micro cutting defects.

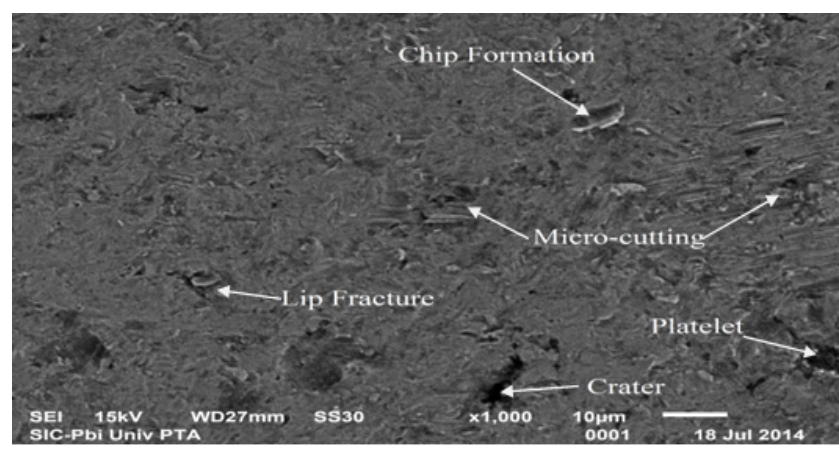

Figure 7. SEM micrograph of SS 304 at $150 \mu \mathrm{m}$ particle size, $10000 \mathrm{ppm}$ concentration level, $20 \mathrm{~m} / \mathrm{sec}$ velocity and $30^{\circ}$ angle of impingement

The figure 7 shows the SEM micrograph of SS304 at conditions $150 \mu \mathrm{m}$ particle size, $10000 \mathrm{ppm}$ concentration level, $20 \mathrm{~m} / \mathrm{sec}$ velocity and $30^{\circ}$ angle of impingement. At these conditions least erosion has been studied and defects occurred are chip formation, micro cutting, lip fracture, platelet and crater defects.

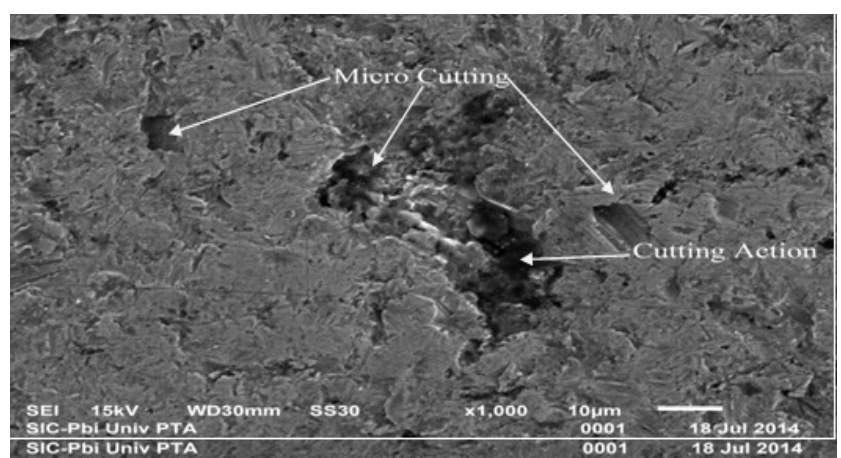

Figure 8. SEM micrograph of SS 304 at $150 \mu \mathrm{m}$ particle size, $30000 \mathrm{ppm}$ concentration level, $60 \mathrm{~m} / \mathrm{sec}$ velocity and $90^{\circ}$ angle of impingement 
The figure 8 shows the SEM micrograph of SS304 at conditions $150 \mu \mathrm{m}$ particle size, $30000 \mathrm{ppm}$ concentration level, $60 \mathrm{~m} / \mathrm{sec}$ velocity and $90^{\circ}$ angle of impingement. At these conditions more erosion has been studied and defects occurred are micro cutting and cutting action defects.

\section{Conclusions}

The conclusions of the experimentation result are listed below:

- The comparison of mass loss shows that erosion rate of SS 304 is more than hard Alloy III and titanium based alloy.

- Erosion resistance of titanium based alloy is better than hard alloy III.

- Hardfacing show better performance than uncoated SS 304 alloy in all experimental conditions.

- For all hard facings, the maximum erosion is at $90^{\circ}$ impact angle and minimum erosion is at $30^{\circ}$.

- The SEM analysis shows that erosion mechanism of under normal impact is platelet mechanism and for substrate material it is due to crack formation.

\section{REFERENCES}

[1] A.P. Harsha and D.K. Bhaskar, "Solid particle erosion behaviour of ferrous and non-ferrous materials and correlation of erosion data with erosion models", 2008, Materials and Design, 29, 1745-1754.
[2] B. Digambar and D. Choudhary, "A review paper on hardfacing processes, materials, objectives and applications", 2014, International Journal of Science and Research, 3(6), 2400-2402.

[3] D. K. Goyal, H. Singh, H. Kumar and V. Sahni, "Slurry erosion behaviour of $\mathrm{HVOF}$ sprayed $\mathrm{WC}-10 \mathrm{Co}-4 \mathrm{Cr}$ and $\mathrm{Al}_{2} \mathrm{O}_{3}$ and $13 \mathrm{TiO}_{2}$ coatings on a turbine steel", 2012,Wear, 289, 46-57.

[4] H.S. Grewal, A. Agrawal and H. Singh, "Slurry erosionperformanceofNi- $\mathrm{Al}_{2} \mathrm{O}_{3}$ based composite coatings",2013, Tribology international,66, 296-306.

[5] R.J.K. Wood, J.C.Walker, T.J. Harvey, S.Wang and S.S. Rajahram, "Influence of microstructure on the erosion and erosion-corrosion characteristics of 316 stainless steel", 2013, Wear, 306, 254-262.

[6] J. Hornung, A. Zikin, K. Pichelbauer, M. Kalin and M. Kirchgabner, "Influence of cooling speed on the microstructure and wear behaviour of hypereutectic $\mathrm{Fe}-\mathrm{Cr}-$ Chardfacings", 2013, Materials science and engineering, A576, 243-251.

[7] C.G. Telfer, M.M. Stack and B.D. Jana, "Particle concentration and size effects on the erosion-corrosion of pure metals in aqueous slurries", 2012, Tribology International, 53, 35-44.

[8] M.D. Bermudez, F.J. Carrion, G.M. Nicolas and R. Lopez, "Erosion-corrosion of stainless steels, titanium, tantalum and zirconium", 2005, Wear, 258, 693-700.

[9] H. Singh, K. Goyal and D.K. Goyal, "Slurry Erosion Behaviour of Plasma Thermal Sprayed (50\%) WC-Co-Cr and Ni-Cr-B-Si Coatings of Different Thickness on CA6NM Turbine Steel Material", Manufacturing Science and Technology 2(4): 81-92, 2014. 